\title{
Right-Sizing the Supreme Court: A History of Congressional Changes
}

Michael C. Blumm

Kate Flanagan

Annamarie White

Follow this and additional works at: https://scholarlycommons.law.case.edu/caselrev

Part of the Law Commons

\section{Recommended Citation}

Michael C. Blumm, Kate Flanagan, and Annamarie White, Right-Sizing the Supreme Court: A History of Congressional Changes, 72 Case W. Rsrv. L. Rev. 9 (2021)

Available at: https://scholarlycommons.law.case.edu/caselrev/vol72/iss1/4

This Article is brought to you for free and open access by the Student Journals at Case Western Reserve University School of Law Scholarly Commons. It has been accepted for inclusion in Case Western Reserve Law Review by an authorized administrator of Case Western Reserve University School of Law Scholarly Commons. 


\title{
Right-Sizing the Supreme Court: A History of Congressional CHANGES
}

\author{
Michael C. Blumm, ${ }^{\dagger}$ Kate Flanagan,${ }^{\dagger \dagger}$ \\ and Annamarie White $e^{i \dagger}$
}

\begin{abstract}
Since the Republican Senate refused to consider President Obama's nomination of Merrick Garland to the Supreme Court in 2016 - coupled with the Trump Administration's success in filling that seat with Neil Gorsuch, followed by the appointments of Brett Kavanaugh and Amy Coney Barrett - there has been widespread interest in how to balance a suddenly solidly conservative Court majority, one likely to remain so for decades. One way to do so is to expand the size of the Court, an issue the Constitution left to Congress, which exercised that authority repeatedly during the Constitution's first eighty years. This article examines those mostly forgotten congressional changes to the Court's size as well as Congress's more notorious failure during the New Deal. The article reveals that the successful expansions were often due to population growth, but were always the product of political calculations. Since the U.S. population is now nearly ten times larger than it was when Congress last changed the Court's size, reconsidering the Court's size may be an issue ripe for congressional consideration, should the political winds suggest that is possible.
\end{abstract}

\section{Contents}

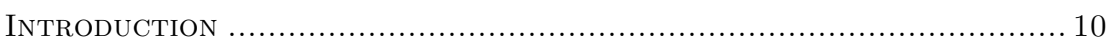

I. The Constitution And the Judiciary ACt of $1789 \ldots \ldots \ldots \ldots \ldots \ldots \ldots \ldots$

A. The Constitution .............................................................. 16

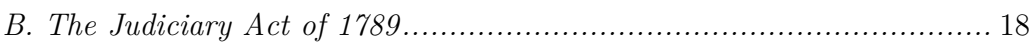

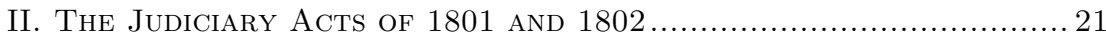

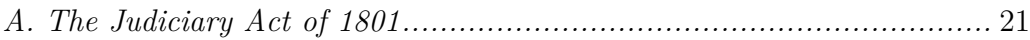

B. The Judiciary Act of 1802...................................................... 23

III. The 1807 And 1837 Judiciary ACts .................................. 25

A. Adding a Seventh Circuit ............................................... 25

$\dagger \quad$ Jeffrey Bain Faculty Scholar \& Professor of Law, Lewis and Clark Law School.

$\dagger$ J.D., 2021, Lewis and Clark Law School; B.A. 2008 (Feminist Studies), University of California, Santa Cruz.

$\dagger \dagger \dagger$ 3L, Lewis and Clark Law School; B.S. 2017, cum laude, Georgetown University. 
B. The Eighth and Ninth Circuits.......................................... 27

IV. The Civil War and Reconstruction Eras.......................... 30

V. The New Deal Era......................................................... 35

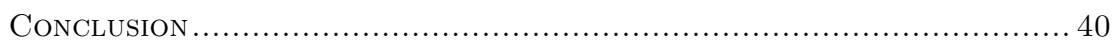

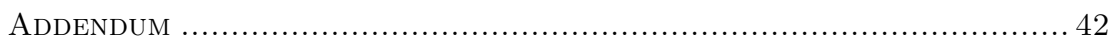

\section{INTRODUCTION}

The Republican Senate's successful maneuvering in 2016 to deny President Obama an opportunity to fill Justice Antonin Scalia's seat, ${ }^{1}$ followed by the rushed confirmation of Justice Amy Coney Barrett to replace Justice Ruth Bader Ginsberg in 2020, ${ }^{2}$ prompted widespread calls for reforming the Court, from calling for a code of ethics to increasing public access to the Court's proceedings. ${ }^{3}$ Among the more prominent suggested reforms are the imposition of term limits ${ }^{4}$ and

1. See generally Ron Elving, What Happened with Merrick Garland in 2016 and Why It Matters Now, NPR (June 29, 2018, 5:00 AM), https://www.npr.org/2018/06/29/624467256/what-happened-with-merrickgarland-in-2016-and-why-it-matters-now [https://perma.cc/6SVL-PVZT].

2. See generally Lisa Mascaro, Barrett Confirmed as Supreme Court Justice in Partisan Vote, Associated Press (Oct. 26, 2020), https://apnews.com/ article/election-2020-donald-trump-virus-outbreak-ruth-baderginsburg-amyconey-barrett-82a02a618343c98b80ca2b6bf9eafe07 [https://perma.cc/PCR7MTSP].

3. The nonpartisan organization "Fix the Court" lobbies for various "fixes" to federal courts, especially the Supreme Court. The Fixes, Fix тHE Cт., https://fixthecourt.com/the-fixes [https://perma.cc/7SRH-7YWB] (last visited Sep. 7, 2021) (proposing "fixes" such as expanding media and public access to Court proceedings, implementing a code of ethics for Supreme Court justices, and requiring detailed and easily accessible financial disclosure reports, among others).

4. Fix the Court endorses term limits for Supreme Court justices. Term Limits, FIX THE CT., https://fixthecourt.com/fix/term-limits/ [https://perma.cc/ D7AQ-BQ9L] (Sep. 29, 2020). The idea of term limits for federal judges is hardly new, as a broad array of leaders from across the political spectrum have discussed the proposal since the ratification era. See, e.g., Michael J. Mazza, A New Look at an Old Debate: Life Tenure and the Article III Judge, 39 GonZ. L. REv. 131, 135-55 (2004) (overviewing the debate over life tenure from 1787 through the late-20th century, and endorsing a system of "rotating offices" for federal judges). A term limit of eighteen years was proposed as a constitutional amendment in 1986. See Philip D. Oliver, Systematic Justice: A Proposed Constitutional Amendment to Establish Fixed, Staggered Terms for Members of the United States Supreme Court, 47 Oніо Sт. L.J. 799, 800-01 (1986) (suggesting staggered, nonrenewable, eighteen-year terms for Supreme Court justices). 
changing the size of the Court to respond to its increasingly partisan makeup. ${ }^{5}$ In response to recent interest in Court reforms, in April, 2021

In 2020, several members of the House of Representatives (Ro Khanna (D-Cal.), Don Beyer (D-Va.), and Joe Kennedy III (D-Mass.)) introduced a bill that would limit every president to two Supreme Court nominations during a four-year term. The bill would also confine the justices' terms to eighteen years on the Supreme Court, then designate them as "Senior Justices," allowing the retirees the opportunity to sit on lower federal courts and rejoin the Court temporarily should there be an unexpected vacancy. See Supreme Court Term Limits and Regular Appointments Act of 2020, H.R. 8424, 116th Cong. Within a month, over thirty legal scholars endorsed the bill. Letter from D. Benjamin Barros, Dean and Professor of L. at Univ. of Toledo Coll. of L., et al. (Oct. 23, 2020) (on file with the Campaign for Supreme Court Term Limits), https://fixthecourt.com/ wp-content/uploads/2020/10/Endorsers-of-H.R.-8424-10.23.20f.pdf [https://perma.cc/4QRL-RU3F]. Current Supreme Court Justices Stephen Breyer and Elena Kagan, along with Chief Justice John Roberts, have also indicated support for term limits. See Amanda Dworkin, Breyer Reaffirms His Support for Term Limits for Justices, FIX THE CT. (Oct. 22 , 2020), https://fixthecourt.com/2020/10/breyer-reaffirms-supportjudicial-term-limits-justices/ [https://perma.cc/R6LM-HCUB]; Term Limits: The Justices' Own Answer to the Broken SCOTUS Confirmation Process, FIX THE CT. (July 7, 2019), https://fixthecourt.com/2019/07/ termlimits/ [https://perma.cc/KRG6-9V7K].

Although fixed term limits may, at first glance, appear to conflict with the constitutional provision allowing justices tenure "during good behavior," almost all legal scholars agree that a term-limit plan like that proposed in the 2020 Supreme Court Term Limits and Regular Appointments Act would not require a constitutional amendment because it would not remove Supreme Court justices after eighteen years, it would merely rotate them to other positions in the federal judiciary. See, e.g., Tyler Cooper, Insight: Fixed Terms for Supreme Court Justices Checks Constitutionality Boxes, Bloomberg LAW (June 3, 2019, 4:01 AM), https://news.bloomberglaw.com/us-law-week/insight-fixed-terms-forsupreme-court-justices-checks-constitutionality-boxes [https://perma.cc/ 87YT-NPZ8]; Kermit RoOsevelt III \& Ruth-Helen Vassilas, Coming to Terms with Term Limits: Fixing the Downward Spiral OF Supreme Court Appointments 11-12 (2017), https://www.acslaw.org/ wp-content/uploads/2017/06/Coming_to_Terms.pdf [https://perma.cc/ ZS6P-24KN] (exploring the problems inherent in Supreme Court appointments in a hyper-partisan process, such as older, out-of-touch justices staying on the bench and the related problem of strategic judicial retirement; and proposing eighteen-year term limits instituted by statute as a solution).

5. See, e.g., Astead W. Herndon \& Maggie Astor, Ruth Bader Ginsburg's Death Revives Talk of Court Packing, N.Y. Times (Oct. 22, 2020), https://www.nytimes.com/2020/09/19/us/politics/what-is-courtpacking.html [https://perma.cc/T3QP-E5FM] (discussing the basic idea of "court packing" and Democratic lawmakers' shifting support in favor of the plan); Matt Ford, The Deradicalization of Supreme Court Reform, New RePublic (Oct. 29, 2020), https://newrepublic.com/article/ 159993/chris-coons-court-packing-barrett [https://perma.cc/L3MR-KW2V] (surveying the debate surrounding court packing in the wake of the 
the Biden Administration created a bipartisan commission made up of prominent attorneys, former judges, and legal scholars ${ }^{6}$ to evaluate

confirmation of Justice Amy Coney Barrett, and arguing that focus should be on the hyper-partisan nature of the Court, rather than on its size).

In addition to calls for establishing term limits and adding seats to the Court, other suggestions include a "Supreme Court Lottery," which would select nine-member Supreme Court panels randomly from all 179 federal appeals-court judges and the current justices, limiting panels to no more than five nominated by a president of a particular political party, and requiring a six-member majority to strike down federal statutes. See Daniel Epps \& Ganesh Sitaraman, How to Save the Supreme Court, 129 YALE L.J. 148, 181, 193 (2019) (proposing a fifteen-justice "Balanced Bench" approach and the Supreme Court lottery system as alternative structures to the current Court). Another proposal would require a sevenmember majority to declare statutes unconstitutional. See, e.g., Ian Millhiser, 9 Ways to Reform the Supreme Court Besides Court-Packing, Vox (Oct. 21, 2020, 12:55 PM), https://www.vox.com/21514454/ supreme-court-amy-coney-barrett-packing-voting-rights [https://perma.cc/ KEZ5-UXJE] (discussing the arguments for and against a supermajority voting requirement, among other ideas for altering the Court or weakening its power). Still others argue that the legislature should take steps to "disempower" the Court by limiting its power to review certain types of federal laws. Ryan D. Doerfler \& Samuel Moyn, Making the Supreme Court Safe for Democracy, New Republic (Oct. 13, 2020), https://newrepublic.com/article/159710/supreme-court-reform-courtpacking-diminish-power [https://perma.cc/8DBD-36FZ] (arguing that socalled "court packing" is not a long-term solution to the Court's political disposition because if the Democrats add seats to the Court now, the next Republican majority will surely do the same; also maintaining that since the Court has been unable practice judicial restraint on its own, Congress should "disempower" the Court through jurisdiction-stripping or supermajority requirements).

6. For a complete list of the Commissioners, see President Biden to Sign Executive Order Creating the Presidential Commission on the Supreme Court of the United States, The White House: Briefing Room (Apr. 9, 2021), https://www.whitehouse.gov/briefing-room/statements-releases/ 2021/04/09/president-biden-to-sign-executive-order-creating-the-presidentialcommission-on-the-supreme-court-of-the-united-states/ [https://perma.cc/ QCW6-CGFN]. In response to the Commission, the President of progressive legal organization the American Constitution Society sent a letter to the Commissioners urging them to "provide a meaningful contribution to restoring the legitimacy of [the] judiciary." See ACS President Urges Court Reform Commission to Act with Urgency, Prioritize Specific Recommendations, Am. Const. Soc'y (May 19, 2021), https://www.acslaw.org/press_release/acs-president-urges-court-reformcommission-to-act-with-urgency-prioritize-specific-recommendations / ?utm_medium $=$ email\&utm_source $=20210521 \_b u l l e t i n[h t t p s: / /$ perma.cc/ STB2-PKEW]. However, while the Commission included legal scholars from both sides of the political aisle, not everyone was satisfied with the program. Some progressives criticized the Commission as merely a means by which President Biden can nullify increasing pressure to expand the Court. See Ian Millhiser, Biden's Supreme Court Reform Commission 
issues facing the federal judiciary. ${ }^{7}$ In the executive order establishing the program, President Biden requested that the Commission issue a

Won't Fix Anything, Vox (Apr. 10, 2021, 8:30 AM), https://www.vox.com/ 2021/4/10/22375792/supreme-court-biden-commission-reform-courtpacking-federalist-society_[https://perma.cc/BG8S-5656]. Conservatives, on the other hand, argued that the program is, in fact, a vehicle to add additional left-wing justices to the bench. See Rep. Jim Jordan (@Jim_Jordan), TwITTER (Apr. 9, 2021, 10:49 AM), https://twitter.com/ Jim_Jordan/status/1380578616040390660 [https://perma.cc/WZB9-JV53] (tweeting, in response to the creation of the Commission, "Why study something we already know? Democrats want to pack the Supreme Court.").

7. Exec. Order No. 14,023, 86 Fed. Reg. 19,569, 19,569 (Apr. 14, 2021); see Biden Starts Staffing a Commission on Supreme Court Reform, POLITICO (Jan. 27, 2021, 2:52 PM), https://www.politico.com/news/ 2021/01/27/biden-supreme-court-reform-463126 [https://perma.cc/97H8CBNU]; Joseph Choi, Biden Begins Staffing Commission to Study Supreme Court Reform: Report, Hill (Jan. 27, 2021, 3:21 PM), https://thehill.com/homenews/administration/536155-biden-administrationbegins-staffing-commission-on-court-reform?rl=1 [https://perma.cc/5LVYBY5A]. The thirty-six-member commission was to examine the structure of the federal court system and generate recommendations to improve a system that, in the president's words, is "getting out of whack." 60 Minutes, Joe Biden: The 60 Minutes 2020 Election Interview, YouTuBE (Oct. 26, 2020), https://www.youtube.com/watch?v=kSAo_1mJg0g. For a transcript of the 60 Minutes interview, see Norah O'Donnell, Joe Biden Makes the Case for Why He Should Be President, CBS News: 60 Minutes (Oct 25, 2020), https://www.cbsnews.com/news/joe-bidendemocratic-presidential-candidate-kamala-harris-60-mintues-interviewnorah-odonnell-2020-10-25/ [https://perma.cc/8GFK-UZ9E].

Proposed changes include adding additional seats to the Court and creating a constitutional court (common in other countries like Germany and France) to resolve constitutional questions and free up the Court to other cases in its increasingly crowded docket. See Joan Biskupic, Biden's Supreme Court Commission Set to Launch as Some Liberals are Eager to Pack the Court, CNN (Jan. 30, 2021, 12:03 PM), https://www.cnn.com/2021/ 01/30/politics/supreme-court-biden-commission/index.html [https:// perma.cc/3EBS-3GST]; Biden Has Created a Commission to Study the Judiciary, ELECTORAL-VOTE.COM (Jan. 28, 2021), https://www.electoralvote.com/evp2021/Pres/Maps/Jan28.html\#item-6 [https://perma.cc/ 2AG4-79FB]; Michael Klarman, The Democrats' Last Chance to Save Democracy, AtLantic (Feb. 22, 2021), https://www.theatlantic.com/ideas/ archive/2021/02/expanding-court-now-or-never/618063/ [https://perma.cc/ 7LMB-SMYP] (urging Democratic lawmakers to quickly add four additional seats to the Supreme Court in order to course-correct the Republican Party's "undermining of democracy" in recent years); Kent Greenfield, Opinion: How to Fix the Supreme Court, N.Y. Times (Oct. 27, 2020), https://www.nytimes.com/interactive/2020/10/27/opinion/ supreme-court-reform.html\#greenfield (proposing that Congress create a "constitutional court" designed to hear constitutional issues and bar such questions from being heard by the Supreme Court unless a supermajority of justices voted to hear the case). 
report by the end of $2021 .{ }^{8}$ The report was to analyze historical and contemporary debates surrounding the Supreme Court's role in the federal system, including how its members are nominated and appointed, but curiously was not expected to produce specific recommendations. The report addressed several proposed modifications for the size and structure of the Court, focusing on the merits and legality of the recommended reforms. ${ }^{9}$ Whether the Commission will

8. Exec. Order No. 14023, 86 Fed. Reg. at 19569 (requiring a report to be delivered to the president within 180 days); Charlie Savage, Biden's Supreme Court Commission May Weigh a Range of Potential Changes Beyond Expanding Seats, N.Y. Times (Apr. 16, 2021), https://www.nytimes.com/ 2021/04/16/us/bidens-supreme-court-commission-may-weigh-a-range-ofpotential-changes-beyond-expanding-seats.html [https://perma.cc/YDR2GWJE] (suggesting that the Commission's first public meeting would be held in May 2021). The report was originally expected in October 2021. See Tyler Pager, Biden Unveils Commission to Study Possible Expansion of Supreme Court, WAsh. Post (Apr. 9, 2021, 5:37 PM), https://www.washingtonpost.com/politics/biden-to-unveil-commission-tostudy-possible-expansion-of-supreme-court/2021/04/09/f644552c-994411eb-962b-78c1d8228819_story.html [https://perma.cc/2HMD-ZVJ5]. But the commission delayed the report until December 2021. Arlette Saenz, Biden Supreme Court Commission Delays Final Report to December 15, CNN: Politics (Nov. 3, 2021, 8:06 AM), https://www.cnn.com/ 2021/11/03/politics/supreme-court-commission-delayed/index.html [https://perma.cc/G4GJ-9LX8].

9. See Pager, supra note 8. The co-chairs of the Commission broke the group down into five working groups, each made up of approximately seven members. See Charlie Savage, Supreme Court Commission to Scrutinize Changes Beyond Expanding Justice Seats, N.Y. Times (Apr. 15, 2021), https://www.nytimes.com/2021/04/15/us/politics/supreme-courtcommission.html [https://perma.cc/STV5-G6QF]. Each working group focused on a different aspect of the Supreme Court debate, working privately to gather information on their respective areas of focus, before presenting their findings to the rest of the Commission at publicly held hearings.

One working group focused on the problems that have consistently plagued the Supreme Court, including historical calls for Supreme Court reform. A second group examined the Court's constitutional role in the federal system and Congress' ability to alter the breadth of the Court's jurisdiction. The third group gathered materials on the length of the justices' terms and collect proposals to limit their tenure via term limits or mandatory retirement ages. A fourth group collected information about the membership and size of the Court, looking in part at how to reduce partisan tensions on the bench. A fifth group looked at concerns regarding the Court's overflowing docket. Id. A related issue, which the Commission considered, is the Court's so-called "shadow docket," including the numerous orders handed down by the Court or its justices each year that generally lack any sort of transparency, such as how each justice voted or the reasoning behind the decision. Id; see also The Supreme Court's Shadow Docket Before the Subcomm. on Cts., Intell. Prop., and the Internet of the H. Comm. on the Judiciary, 117th Cong. (2021) (testimony 
lead to any lasting change is quite unclear. However, the idea is not new. There is a long history of interest among the political branches to change the Court's composition and its procedures. ${ }^{10}$

In April 2021, a bill that would add four members to the Supreme Court was presented by House Judiciary Committee Chair Jerry Nadler (D-N.Y.) along with co-sponsors, Representatives Hank Johnson (DGa.) and Mondaire Jones (D-N.Y.). ${ }^{11}$ Senator Ed Markey (D-Mass.) simultaneously introduced the "Judiciary Act of 2021" in the Senate. ${ }^{12}$ The House Judiciary Committee's press release emphasized Nadler's remarks that the bill would conform the number of justices to the number of circuits, as Congress had done from the creation of the Court until the time of the Civil War. ${ }^{13}$ Neither Senate Judiciary Chair Dick Durbin nor House Speaker Nancy Pelosi expressed immediate support for the bill, telling reporters that they would wait for the recommendations of the presidential commission. ${ }^{14}$ With Democrats' thin majority

of Stephen I. Vladeck, Charles Alan Wright Chair in Federal Courts, University of Texas School of Law), https://www.justsecurity.org/wpcontent/uploads/2021/02/Vladeck-Shadow-Docket-Testimony-02-182021.pdf [https://perma.cc/PTL7-DLGK] (exploring the history of the "shadow docket," including its increasing use in recent years, the various problems it presents, and suggesting congressional reform to both curtail and standardize its use).

10. For example, in the 1970s, scholars debated the wisdom of establishing a National Court of Appeals to respond to the mounting number of cases seeking Supreme Court review. The new court would have consisted of seven rotating appellate-court judges tasked with reviewing all appeals, including resolving circuit splits, referring only the most "review-worthy" cases to the Supreme Court. See, e.g., Paul A. Freund, Why We Need the National Court of Appeals, 59 A.B.A. J. 247, 247, 250 (1973) (arguing that the unprecedented caseload of the Supreme Court warranted change and the National Court of Appeals would be the least disruptive solution); cf. Charles L. Black, Jr., The National Court of Appeals: An Unwise Proposal, 83 YALE L.J. 883, 883, 885, 887 (1974) (challenging the proposal on both constitutional and public-policy grounds).

11. Expand the Supreme Court: Reps. Nadler, Johnson, and Jones and Senator Markey Introduce Legislation to Restore Justice and Democracy to Judicial System, U.S. House Comm. on the Judiciary: Press Releases (Apr. 15, 2021), https://judiciary.house.gov/news/documentsingle.aspx? DocumentID $=4508$ [https://perma.cc/E5P3-JHE6].

12. Judiciary Act of 2021, S. 1141, 117th Cong. (2021).

13. Chairman Nadler Remarks at Press Conference Announcing Introduction of Judiciary Act of 2021, U.S. House Comm. On The Judiciary: Press ReleAses (Apr. 15, 2021), https://judiciary.house.gov/news/document single.aspx?DocumentID=4510 [https://perma.cc/H3E3-6VSY].

14. Andrew Chung \& David Morgan, Cool Reception for Democratic Proposal to Expand U.S. Supreme Court, Reuters (Apr. 15, 2021, 9:50 AM), https://www.reuters.com/world/us/democrats-unveil-bill-expand-ussupreme-court-by-four-justices-2021-04-15/ [https://perma.cc/6MHL-T2PP]. 
in the Senate, any reluctance from leadership to move the bill forward would likely kill the bill's chances of being enacted.

Given these recent developments, it seems propitious to survey the history of successful congressional efforts to change the size of the Court, which began in the Founding Era and continued throughout antebellum America. The Court's size ranged from six members to ten before settling on nine in $1869 .{ }^{15}$ The size of the Court was a function of the political dynamics of the day, as Congress enlarged the Court to enable favored presidents to appoint new members and constricted the Court to deny appointments to those Congress disfavored. ${ }^{16}$ The politicization of the size of the Court continued largely unimpeded until President Franklin Roosevelt and his New Deal ran into the well-known conflict with a Republican Supreme Court, as discussed in Part V of this article. Parts I-IV explain the expansions and contraction during the 19th century. The article concludes that, despite the apparent lessons drawn from the so-called "court packing" efforts of FDR, political control of the size of the Court is unassailable. There may be reasons to retain the current nine-member Court, but they are clearly not of a constitutional or historical nature.

\section{The Constitution And the Judiciary ACt of 1789}

\section{A. The Constitution}

Article III of the Constitution provided only a rough outline of the federal judiciary. Significantly shorter than Articles I and II, Article III established "one supreme Court" and any "inferior Courts as the Congress may from time to time ordain and establish." ${ }^{17}$ Although the Framers decided early in the constitutional debates in Philadelphia to establish a Supreme Court, ${ }^{18}$ they did not establish the size of the Court. Instead, the constitutional debates discussed how the federal judiciary would interact with the other two branches of government, ${ }^{19}$ the

15. Why Does the Supreme Court Have Nine Justices? NAT'L Const. CTR.: Const. Daily (July 6, 2018), https://constitutioncenter.org/blog/whydoes-the-supreme-court-have-nine-justices [https://perma.cc/Z5DE-DLEP].

16. Id.

17. U.S. Const. art. III, § 1 .

18. Fed. Jud. Hist. Off., Fed. Jud. Ctr., Constitutional Origins of THE Federal Judiciary 1-2 (2005), https://www.fjc.gov/sites/default/ files/pdf/ConstitutionalOrigins.pdf [https://perma.cc/Z9EF-7J6K].

19. See, e.g., James Madison's remarks in 2 The RECORds of THE FEDERAL Convention of 1787, at 74 (Max Farrand ed., 1911) (discussing the proposition of providing the judiciary with revisionary power over laws passed by the legislature, Madison argued that such a power would be "useful to the Judiciary departmt. [sic] by giving it an additional opportunity of defending itself agst: [sic] Legislative encroachments."). 
justices' tenure and compensation ${ }^{20}$ and the judiciary's jurisdictional bounds. ${ }^{21}$ The most contentious debate concerning the judiciary was whether to establish lower federal courts. ${ }^{22}$

Federalists pressed for the creation of lower federal courts to serve as the principal trial courts for legal disputes under federal purview. ${ }^{23}$ In letters from Philadelphia, delegates acknowledged pressure to create a system of government that balanced the power of individual states with that of the new nation. ${ }^{24}$ After the Constitution was sent to the states for ratification, Anti-Federalists, alarmed at the possibility that federal courts might usurp the responsibilities of state courts, vehemently opposed the establishment of lower federal courts. ${ }^{25}$ Supporters like Alexander Hamilton maintained that, compared with the legislative and executive branches, a federal judiciary would "be the least dangerous to the political rights of the constitution." 26 The drafters decided not to resolve the issue of the size of the Court, leaving the matter to Congress. ${ }^{27}$

20. Journal, Acts and Proceedings of the Convention, Assembled at Philadelphia, Monday, May 14, and Dissolved Monday, September 17, 1787 Which Formed the Constitution of the United States 69 (Thomas B. Wait 1819) [hereinafter Journal, ACts and Proceedings of the Convention, Assembled].

21. Id. at $188-89$.

22. See Richard W. Garnett \& David A. Strauss, Article III, Section One, NAT'L Const. CTR.: InTERACTIVE Const., https://constitutioncenter.org/ interactive-constitution/interpretation/article-iii/clauses/45 [https:// perma.cc/7ECK-CEAX] (last visited Sep. 5, 2021).

23. Fed. Jud. Hist. OfF., supra note 18, at 2, 5-7.

24. See, e.g., Letter from Pierce Butler to Weeden Butler (Oct. 8, 1787), in 24 Letters of Delegates to Congress, November 6, 1786February 29, 1788, at 470-72 (Paul H. Smith \& Ronald M. Gephart eds., 1996) ("We had Clashing Interests to reconcile-some strong prejudices to encounter, for the same spirit that brought settlers to a certain Quarter of this Country, is still alive in it.").

25. See, e.g., Letters of "Brutus", in 1 The Debate on the Constitution 168 (Bailyn ed., 1993), reprinted in Fed. Jud. Hist. Off., supra note 18, at 18; Nathaniel Breading et. Al, The Address and Reasons of Dissent of the Minority of the Convention, of the State of Pennsylvania, to Their Constituents 1 (Dec. 12, 1787), https://www.loc.gov/resource/bdsdcc.c0401 [https://perma.cc/WH7AMLW6].

26. The Federalist No. 78, at 522 (Alexander Hamilton) (Jacob E. Cooke ed., 1961).

27. See Journal, Acts And Proceedings, of the Convention, Assembled, supra note 20, at 363 (authorizing Congress to create lower courts whose judges would hold their offices during good behavior and receive a salary "which shall not be diminished during their continuance in office"). 


\section{B. The Judiciary Act of 1789}

The nation's new federal government officially began on March 4, $1789 .^{28}$ The judiciary was immediately at the top of the first Congress's agenda. The first bill introduced in the Senate would become the Judiciary Act of $1789 .^{29}$

The First Congress debated whether to establish lower federal courts and the size of the Supreme Court, deciding on the unlikely number of six justices. ${ }^{30}$ Six was the choice because the bill divided the country into thirteen district courts and three geographical circuits. ${ }^{31}$ Each district bench would have one federal judge who would primarily hear admiralty and maritime cases, as well as other minor suits. ${ }^{32}$ Unlike appellate circuit courts of the modern judiciary (which were established in the Judiciary Act of 1891), the original circuit courts exercised only limited appellate jurisdiction over the district courts. ${ }^{33}$ Their primary function was instead to serve as the principal federal trial courts of the

28. See The Day the Constitution Was Ratified, NAT'L Const. Ctr. (June 21, 2021), https://constitutioncenter.org/blog/the-day-the-constitutionwas-ratified [https://perma.cc/3R4T-ZNSM].

29. See The Court as an Institution, SuP. CT. OF THE U.S., https://www.supremecourt.gov/about/institution.aspx [https://perma.cc/ N4BB-9HCS] (last visited Sep. 5, 2021). Chaired by Connecticut senator Oliver Ellsworth, a committee began to draft the bill on April 7, 1789, the day after the Senate achieved its first quorum. Senator Ellsworth's Judiciary Act, U.S. SENATE, https://www.senate.gov/artandhistory/history/ minute/Senator_Ellsworths_Judiciary_Act.htm [https://perma.cc/6ZM6UZKS] (last visited Oct. 29,2021 ). With debates over ratification still fresh in the national conscience, the Senate distributed the proposed legislation to constituents and invited comments prior to debating the bill. Landmark Legislation: Judiciary Act of 1789, FED. Jud. CTR., https://www. fjc.gov/history/legislation/landmark-legislation-judiciary-act-1789-0/ [https://perma.cc/455U-KGZQ] (last visited Oct. 29, 2021). Within the committee, Ellsworth represented the Federalist viewpoint and Richard Henry Lee of Virginia voiced the Anti-Federalist perspective. See Wythe Holt, "To Establish Justice": Politics, the Judiciary Act of 1789, and the Invention of the Federal Courts, 1989 Duke L.J. 1421, 1480-81. The two men worked together to create a bill acceptable both to Federalists and Anti-Federalists. See id. at 1481-85. Section 11 of the bill, establishing the lower federal courts, fixed the number of justices to be appointed to the Supreme Court at six. See Charles Warren, New Light on the History of the Federal Judiciary Act of 1789, 37 Harv. L. Rev. 49, 76 (1923).

30. See Holt, supra note 29 , at $1485-86$.

31. Judiciary Act of 1789 , ch. $20, \S \S 1-2,4,1$ Stat. 73, 73-75.

32. Landmark Legislation: Judiciary Act of 1789, supra note 29.

33. Russell R. Wheeler \& Cynthia Harrison, Fed. Jud. Ctr., Creating the Federal Judicial System, 4, 24 (1989), https://www.ojp.gov/pdffiles1/ Digitization/120728NCJRS.pdf [https://perma.cc/TN7D-TW7U]. See infra note 82 for details on the Judiciary Act of 1891 . 
day. ${ }^{34}$ Each circuit court consisted of a panel of one local district judge and two travelling Supreme Court justices..$^{35}$ Consequently, part of the job description for the Chief Justice and the five associate justices was to "ride circuit." ${ }^{36}$ Two justices assigned to each of the three circuits made a six-justice Court a reasonable choice, especially since it saved money by making separate circuit-court judges unnecessary. ${ }^{37}$ The

34. Id. at $4,7-9$.

35. Judiciary Act of 1789, ch. 20, § 4, 1 Stat. 73, 74-75.

36. See Dale Yurs, The Early Supreme Court and the Challenges of Riding Circuit, 36 J. Sup. Cт. Hist. 181, 183 (2011).

37. Although deciding to establish lower federal courts, Ellsworth sought to appeal to Anti-Federalists by imposing jurisdictional limits on federal courts. Questions of federal law would be tried in state courts only. Appeals could go only to the Supreme Court, not an intermediary federal court, and only when the decision by the highest state court ruled against the federal law in question. The bill also limited the Supreme Court's appellate jurisdiction to review only errors of law, not issues of fact. See Holt, supra note 29, at 1485-86 (discussing the compromises in the bill). Opponents of the Ellsworth bill included its co-author, Richard Henry Lee, who worked with William Grayson, also of Virginia, to put forth "The Virginia Plan," which would have replaced the proposed district courts with existing state trial courts. Id. at 1490-91. After that plan failed, William Samuel Johnson of Connecticut proposed to replace the district and circuit courts with a large, undetermined number of traveling Supreme Court justices, an idea swiftly defeated in the Senate. See id. at 1493.

The most vocal opponent of Ellsworth's plan was William Maclay of Pennsylvania. Although Maclay entered the legislature as a Federalist, he quickly developed strong Anti-Federalist positions. See Journal of William Maclay, U.S. SEnATE, https://www.senate.gov/reference/reference item/Maclay.htm [https://perma.cc/6S3P-TEWZ] (last visited Sep. 4, 2021, 3:23 PM). Of the Judiciary Bill, Maclay wrote in his diary: "I do not like it in any part." Entry of May 11, 1789, in Journal OF William Maclay, United States Senator from Pennsylvania, 1789-1791, at 30 (Edgar S. Maclay ed., 1891) [hereinafter Journal OF William Maclay]. The Senate debated the proposed bill for seventeen days. See Hampton L. Carson, The Supreme Court of the United States: Its History 128-29 (1891). When the debate turned to the number of Supreme Court justices, opinions varied considerably. William Grayson, the Virginia Plan having been defeated, supported the suggested six. Id. at 130. Maclay, on the other hand, believed that six was too few if the circuit courts were established, and too many if they were not. At one point, Ellsworth took the floor and argued for a court of twelve. In support of a larger bench, Ellsworth emphasized the importance of the cases that would be before the Supreme Court, mentioning the twelve judges of the Court of Exchequer. Maclay responded by pointing out the considerable difference in the number of cases being heard by the English court, and those which would reach the Supreme Court. He suggested that perhaps once the amount of cases being heard by the Supreme Court increased, it would be appropriate to expand the Court in response. Maclay also emphasized the idea that more justices on the Court would diminish the 
unstated assumption was that the Supreme Court's size was more a function of its role in overseeing lower federal courts than of the danger of deadlocks over doctrine. ${ }^{38}$

Appointing the district judges and Supreme Court justices was a task for the newly inaugurated President George Washington, with the consent of the Senate. ${ }^{39}$ Washington quickly nominated John Jay for Chief Justice on September 24, 1789, the day he signed the Act. ${ }^{40}$ The Senate confirmed Jay just two days later. ${ }^{41}$ Thus, two years after the Framers signed the Constitution, and fifteen months after ratification, Article III's sketch of the federal judiciary began to be fulfilled.

responsibility of each individual justice, maintaining that it was more important to place "eminent characters" on the bench than to have a large Court. For Maclay's full version of events, see Entry of June 23, 1789, in Journal of William Maclay, supra, at 87-88. The Senate settled on a Supreme Court consisting of one Chief Justice and five Associate justices. See CARson, supra, at 131.

Once the judiciary bill passed the Senate, deliberations surrounding the legislation simmered. The House did entertain a brief discussion about the number of Supreme Court justices, however. On the first day of deliberations, Samuel Livermore of New Hampshire moved to reduce the number of Associate Justices to three. Interestingly, James Jackson, an Anti-Federalist, challenged this idea by pointing out that an issue would inevitably arise when the court was split $2-2$. No one pointed out that the same fate might befall a court of six. Instead, Egbert Benson, a Federalist, urged the House to pass the bill without much deliberation, as the Senate had debated the issue at length, and the congressional term was drawing to a close. See 1 Annals of Cong. 782 (1789) (Joseph Gales ed., 1834). The House debated the bill on three more occasions without revisiting the number of justices before passing it with a handful of amendments, which the Senate concurred in and supplemented. The House passed the final version of the Judiciary Act of 1789 on September 21, 1789. Id.

38. See Yurs, supra note 36, at 183.

39. Washington had the benefit of a Senate with 18 pro-administration members and just 8 anti-administration members. See Party Division: 1st Congress, U.S. SEnATE, https://www.senate.gov/history/partydiv. htm\#: :text=1st\%20Congress \% 20(1789\%2D1791)\&text=Those\%20who \%20supported\%20the\%20Washington,emerging\%20(Jeffersonian)\%20Re publican\%20party [https://perma.cc/2PU6-GKU3] (last visited Sep. 5, 2021). The House had 37 pro-Administration members and 28 antiadministration members. See Congress Profiles: 1st Congress, U.S. House OF Representatives, https://history.house.gov/CongressionalOverview/Profiles/1st/ [https://perma.cc/YH7Z-VD9C] (last visited Sep. $5,2021)$.

40. Supreme Court Nominations (1789-Present), U.S. SENATE, https://www. senate.gov/legislative/nominations/SupremeCourtNominations1789present. htm [https://perma.cc/FW9P-DHGG] (last visited Sep. 5, 2021).

41. Id. 


\section{ThE JUdiCIARY ACTS OF 1801 AND 1802}

\section{A. The Judiciary Act of 1801}

Circuit riding was arduous. Both physically and mentally taxing, the obligation quickly became unpopular among the justices. Justices complained that it required traversing as many as 1,900 miles (on bad roads and inconsistent ferries) within a single circuit. ${ }^{42} \mathrm{~A}$ number declined judicial nominations or resigned from the bench rather than continue the odious duty. ${ }^{43}$ Those who remained on the Court wrote President Washington on at least two occasions, in 1790 and 1792, expressing their intense dislike of the practice. ${ }^{44}$ All six justices also penned their disapproval to Congress in 1792, imploring the legislature to drop the circuit-riding requirements established by the 1789 Act. ${ }^{45}$ These efforts proved to be only somewhat successful: in 1793, Congress responded by reducing the number of justices required to visit each circuit from two to one, cutting the justices' circuit riding in half. ${ }^{46}$

The reduction in circuit-riding quieted the discussion surrounding circuit courts for a time. ${ }^{47}$ Towards the end of 1799 , however, the impending election of 1800 thrust the courts back into the spotlight. President John Adams and his Federalist supporters, worried over the apparent increasing political strength of the nascent Republican Party, undertook a vigorous campaign to expand the federal judiciary to maintain their control. ${ }^{48}$ Federalist majorities in both houses of Congress began crafting what would become the Judiciary Act of $1801,{ }^{49}$ described as "An Act to provide for the more convenient organization of the Courts of the United States." 50

42. John V. Orth, How Many Judges Does It Take to Make a Supreme Court?, 19 Const. Comment. 681, 683 (2002).

43. Yurs, supra note 36, at 183.

44. Id. at 186 .

45. Id. at $186-87$.

46. Orth, supra note 42 , at 683 .

47. Yurs, supra note 36 , at 187.

48. See Kathryn Turner, Federalist Policy and the Judiciary Act of 1801, 22 WM. \& MARY Q. 3, 9 (1965).

49. See id. at 9-10. Notably, the committee in the House included future Chief Justice John Marshall. Id. at 10. Marshall was a member of the House of Representatives from March 4, 1799 to June 7, 1800, including time served on the committee to revise the judiciary system. Id.; John Marshall, U.S. House of Representatives: Hist., Art \& Archives, https://history.house.gov/People/Listing/M/MARSHALL,-John-(M000157)/ [https://perma.cc/S9CD-HXED] (last visited Oct. 23, 2021). In June of 1800, Marshall resigned from the House to become Secretary of State. Id.

50. Judiciary Act of 1801, ch. 4, 2 Stat. 89, 89. 
The House first considered the new judiciary bill on March 11, $1800 .^{51}$ In its original form, the bill decreased the number of Supreme Court justices from six to five and abolished the district courts. ${ }^{52}$ It would have re-divided the nation into twenty-nine districts, forming nine circuits, each with its own circuit judge. ${ }^{53}$ Since each of these new judgeships would need to be filled, the bill provided an opportunity for the Adams administration to appoint Federalist judges across the country, thereby cementing the Federalists' hold on the judiciary in what turned out to be the waning days of the Adams Administration. Debate over the bill raged in the House for weeks. Ultimately, the bill's key provision, establishing the twenty-nine districts, was narrowly defeated on March 27, 1800. ${ }^{54}$ The Republican opponents of the bill successfully postponed the issue until after the election of $1800 .{ }^{55} \mathrm{In}$ that landmark election, Thomas Jefferson and the Republicans narrowly defeated Adams and the Federalists..$^{56}$

The Republican electoral victory led the outgoing Federalists to use the lame-duck session of Congress to attempt to cement their control over the federal judiciary, having lost both the presidency and Congress. ${ }^{57}$ In mid-December 1800, Chief Justice Oliver Ellsworth resigned to give President Adams an opportunity to appoint his successor, and Adams swiftly nominated John Jay, the original Chief Justice, to replace him. ${ }^{58}$ Jay declined, however, so Adams appointed his Secretary of State, John Marshall, who was quickly approved by the outgoing Federalist majority in the Senate. ${ }^{59}$ On January 20, 1801, the

51. See Turner, supra note 48 , at 11 .

52. See $i d$.

53. $I d$.

54. 10 AnNals of Cong. 646 (1800).

55. See Turner, supra note 48 , at 14.

56. 10 Annals of Cong. 1024 (1801). Jefferson (and Burr) won the electoral vote over Adams (and Pinckney), 73-65, although the popular vote was not so close. With just $32.3 \%$ of eligible voters voting, the Republican ticket won $41,330(61.4 \%)$ to $25,952(38.6 \%)$ for the Federalist ticket. Electoral vs. Popular Votes, Norwich Univ. Online (Dec. 1, 2015), https://online.norwich.edu/academic-programs/resources/electoral-vspopular-votes [https://perma.cc/U8FN-YDRN].

57. Turner, supra note 48 , at 15 . After the election, Republicans controlled both houses of Congress and the presidency. The Republican majority in the Senate was 17-15, while in the House the Republican majority was 68-38. See Party Division: 7th Congress, U.S. SENATE, https://www.senate.gov/history/ partydiv.htm [https://perma.cc/ZZZ2-B48U]; Congress Profiles: 7th Congress (1801-1803), U.S. House of Representatives: Hist., Art \& ArCHIVES, https://history.house.gov/Congressional-Overview/Profiles/7th/ [https://perma.cc/X2DH-8AM9].

58. See Turner, supra note 48 , at $14-15$.

59. S. Exec. Journal, 6th Cong., 2d. Sess. 374 (1801). 
same day that President Adams nominated Marshall as Chief Justice, the House approved the judiciary bill. ${ }^{60}$

The bill then moved to the Senate, where the lame-duck Federalist majority tried to push it through without amendment, while the Republicans sought to delay its passage until Adams' term expired. ${ }^{61}$ At one point, the Senate considered and rejected a motion that would have increased the size of the Supreme Court to eight. ${ }^{62}$ With just a month left in the Federalist administration, the Senate approved the House bill, and President Adams signed the Judiciary Act of 1801 into law on February 13, 1801. ${ }^{63}$ The Act established six circuits, each with three resident circuit judges (except the sixth circuit, which had only one), which - much to the justices' relief - eliminated the need for circuit riding. ${ }^{64}$ This provision entitled Adams to sixteen judicial appointments (the so-called "midnight judges"), which he moved quickly to fill before his term expired. ${ }^{65}$

A related statute, passed a couple of weeks later, added three additional circuit judgeships and more than forty justices of the peace ${ }^{66}$ That Act also would have also decreased the Supreme Court from six justices to five, the first instance of Congress altering the size of the Supreme Court. ${ }^{67}$ The diminished size was clearly a partisan measure, aimed at depriving incoming President Jefferson of filling the next vacancy on the Court. This attempt to downsize the Court motivated the incoming Republican Congress to overturn the 1801 Act once the lame-duck session ended. ${ }^{68}$

\section{B. The Judiciary Act of 1802}

In March 1802, with the Republicans in control of both houses of Congress and the presidency, Congress reversed the Federalists'

60. See Id. at 371 (1801); H. Journal, 6th Cong., 2d. Sess. 767 (1801). The Senate approved Marshall as Chief Justice only seven days later. S. ExEC. Journal, 6th Cong., 2d. Sess. 374 (1801).

61. See Turner, supra note 48, at 19-20; see also S. Journal, 6th Cong., 2d. Sess. 121-23 (1801) (showing that the Senate majority consistently rejected any amendments to the bill).

62. 10 Annals of Cong. 740-41 (1801).

63. See Kathryn Turner, The Midnight Judges, 109 U. PA. L. REv. 484, 495 (1961).

64. See id. at 494-95.

65. See id.

66. See id. at 517-19; Act of Feb. 27, 1801, ch. 15, § 3, 2 Stat. 103, 105-06 ("An Act concerning the District of Columbia."); id. § 11, 2 Stat. at 107.

67. See Erwin C. Surrency, The Judiciary Act of 1801, 2 Am. J. Legal Hist. 53,62 (1958).

68. See $i d$. at $63-64$. 
expansion of the judiciary ${ }^{69}$ One of the first acts of the new Congress, passed on March 8, 1802, repealed the 1801 Act. $^{70}$ The 1802 statute rescinded the new circuit courts, restored the old circuits, reinstituted circuit riding, and returned the size of the Supreme Court to six justices. ${ }^{71}$

This Act was the second time Congress changed the Court's size for partisan reasons. The repeal of the lower court additions led one disappointed justice-of-the-peace appointee, William Marbury, to initiate what became the most consequential case in Supreme Court history. ${ }^{72}$ The Act also abolished the 1802 term of the Court, so Marbury's suit would not be heard that year. ${ }^{73}$

Having repealed the 1801 Act in March, the Republican Congress aimed to pass a judiciary act of its own. One month later, Congress passed, and President Jefferson signed, the Judiciary Act of 1802-

69. See Jed Glickstein, Note, After Midnight: The Circuit Judges and the Repeal of the Judiciary Act of 1801, 24 Yale J.L. \& Human. 543, 550 (2012).

70. Act of Mar. 8, 1802, ch. 8, § 1, 2 Stat. 132, 132 ("An Act to repeal certain acts respecting the organization of the Courts of the United States; and for other purposes.").

71. Id. $\S \S 1-5,2$ Stat. at 132.

72. See Glickstein, supra note 69 , at 544. Along with the circuit courts, the midnight judges and ancillary appointments were rescinded or, for those who had yet to receive them, denied their commissions. Id. One of the justices of the peace denied his commission was William Marbury, who sued Secretary of State James Madison in an attempt to force the Jefferson administration to honor his appointment. $I d$.

73. Id. at 550. The justices would not meet again in Washington until the following February, when they would finally take up the issue of whether the repeal act was, in fact, constitutional. Id. Chief Justice Marshall, a Federalist who had helped draft the 1801 Act, handed down the landmark decision in Marbury v. Madison, 5 U.S. (1 Cranch) 137 (1803), on February 24, 1803. Marshall wrote for a unanimous 4-0 Court against Marbury (Justice William Cushing missed the entire February term due to illness, and Justice Alfred Moore had not yet arrived from North Carolina; so neither sat for oral argument or participated in the Court's decision). See Marbury, 5 U.S. (1 Cranch) at 180; see also RoBerT Strauss, John Marshall: The Final Founder, 126 (2021). Marshall decided that the Supreme Court lacked jurisdiction to restore Marbury's judgeship, declaring a provision of the 1789 Judiciary Act that expanded Article III's grant of original jurisdiction of the Court to be an unconstitutional expansion of judicial authority, establishing judicial review of the constitutionality of legislation. Marbury, 5 U.S. at 177-80. Later, in 1803, the Court upheld the authority of Congress in the 1802 Act to abolish the midnight judgeships in Stuart v. Laird, 5 U.S. (1 Cranch) 299, 308-09 (1803), from which Marshall recused himself. See Glickstein, supra note 69 , at 555-56. 
which again divided the country into six judicial circuits. ${ }^{74}$ The 1802 circuits were similar, though not identical, to the six circuits established in $1801 .{ }^{75}$ Consequently, the Act did not change the size of the Supreme Court. Having already restored the number of justices to six with the first 1802 Act, Congress provided President Jefferson the opportunity to appoint a justice at the next vacancy, which he seized by nominating William Johnson in May of $1804 .{ }^{76}$

\section{The 1807 AND 1837 JUdICIARY ACTS}

\section{A. Adding a Seventh Circuit}

Following the tumult of 1801 and 1802, the judiciary was in relative political peace for half a decade. Kentucky, which achieved statehood in 1792, ${ }^{77}$ and Ohio had been included in the short-lived sixth circuit created by the Judiciary Act of $1801 .^{78}$ But neither was included in a circuit in the 1802 Act. ${ }^{79}$ Instead, when organizing the judicial districts for Kentucky, Ohio, and Tennessee, Congress exempted the new western states from the traditional circuit structure. ${ }^{80}$ Separated from the rest of the circuits by the Appalachian Mountains, Congress considered the new western states too distant for circuit-riding Supreme Court justices to reach. ${ }^{81}$ Consequently, the federal district courts in these three states retained the trial jurisdiction usually reserved for the federal circuit courts, and all appeals went directly to the Supreme Court. $^{82}$

74. Judiciary Act of 1802, ch. 31, § 4, 2 Stat. 156, 157 ("An Act to amend the Judicial System of the United States.").

75. Compare id., with Judiciary Act of 1801, ch. 4, § 6, 2 Stat. 89, 90.

76. Justices 1789 to Present, Sup. CT. OF THE U.S., https://www. supremecourt.gov/about/members_text.aspx [https://perma.cc/4JPM$5 \mathrm{MHX}]$ (last visited Sept. 1, 2021).

77. COMm. On the Judiciary, One Hundred And Seventy-Fifth Anniversary OF the Admission of the Commonwealth OF Kentucky to the Union, S. Rep. No. 90-247, at 2 (1967).

78. Judiciary Act of $1801 \S 4,2$ Stat. at 89-90.

79. See Judiciary Act of $1802, \S 4,2$ Stat. at 157 (excluding Kentucky and Ohio from the list of districts included in the six circuits).

80. See id.; Landmark Legislation: Seventh Circuit, FED. Jud. CTR., https://www.fjc.gov/history/legislation/landmark-legislation-seventh-circuit [https://perma.cc/E6AA-ZPB4] (last visited Sept. 15, 2021).

81. Landmark Legislation: Seventh Circuit, supra note 80.

82. Id. Because Congress thought that circuit riding was too difficult for justices in these three western states, the justices were exempted from the circuit system when the 1802 Act redrew circuit lines. Instead, local 
Meanwhile, the United States' westward expansion was rapidly underway, enthusiastically encouraged by Jefferson. ${ }^{83}$ Within the first half of the new decade, population growth made it apparent that the existing judicial structure was inadequate. The nation's rapid western settlement induced a raft of federal lawsuits in the western states, including complicated diversity cases resulting from disputes over federal land claims. ${ }^{84}$ As a result, in early 1807, the Senate advanced a bill to establish circuit courts in Kentucky, Tennessee, and Ohio. ${ }^{85}$ The bill proposed a seventh circuit and an expansion of the Supreme Court's size from six justices to seven members. ${ }^{86}$ The resulting 1807 Act integrated the new circuit for the western districts into the judicial system. But it also included a residency requirement, requiring the newly authorized Supreme Court justice to reside within the new Seventh Circuit. ${ }^{87}$ Presumably included to address the realities of circuit riding in the western district, the requirement was the only residency provision in the judiciary acts. ${ }^{88}$

district courts in these states assumed the trial function usually reserved for the circuit courts. Id.

The appellate courts as we know them today (as the U.S. Courts of Appeals) were not established until Congress enacted the Judiciary Act of 1891, which stripped the old circuit courts of most of their appellate jurisdiction, transferring appellate power to the new circuit courts of appeals, but left them in place as trial courts. Act of March 3, 1891, ch. $517, \S 2,26$ Stat. 826, 827 ("An act to establish circuit courts of appeals and to define and regulate in certain cases the jurisdiction of the courts of the United Sates, and for other purposes."); see Appellate Jurisdiction Transferred to New Courts, FED. Jud. CTR., https://www.fjc.gov/ history/timeline/appellate-jurisdiction-transferred-new-courts [https:// perma.cc/D5VH-WX8L] (last visited Sep. 26, 2021).

The old circuit courts were officially terminated in the Judicial Code of 1911, Pub. L. No. 61-475, 36 Stat. 1087, leaving the district courts as federal trial courts and the courts of appeals as the middle tier of the judiciary. Id. $\S \S 1,117,36$ Stat. at 1087, 1131; see Circuit Riding, FED. JuD. CTR., https://www.fjc.gov/history/timeline/circuit-riding [https://perma.cc/ E27H-84RB] (last visited Sep. 26, 2021).

83. Thomas Jefferson, LiBR. OF CONG., https://www.loc.gov/exhibits/jefferson/ jeffwest.html [https://perma.cc/6D72-WDXH] (last visited Sept. 15, 2021).

84. Landmark Legislation: Seventh Circuit, supra note 80.

85. Seventh Circuit Act of 1807, ch. 16, § 2, 2 Stat. 420, 420 ("An Act establishing Circuit Courts, and abridging the jurisdiction of the district courts in the districts of Kentucky, Tennessee and Ohio."); 16 AnNALs of Cong. 46 (1807) (showing the Senate's passage of the corresponding bill).

86. Seventh Circuit Act of $1807 \S \S 2,5,2$ Stat. at 420, 421.

87. $I d$.

88. Landmark Legislation: Seventh Circuit, supra note 80. 
Congress enacted the 1807 Act with little fanfare, making its way from the Senate to the House, where it passed $82-7.89$ The addition of a seventh justice by the Republican Congress - the third change to the size of the Court in six years - gave the Republican Jefferson the opportunity to appoint Thomas Todd to the Court. ${ }^{90}$ With the federal government under complete Republican control, the Seventh Circuit Act of 1807's expansion of the Court, giving the Republican president a new appointment, was considerably less controversial than the fractious 1801 and 1802 statutes.

\section{B. The Eighth and Ninth Circuits}

For thirty years following the creation of the Seventh Circuit, the judicial system remained largely unchanged. In 1820, Maine achieved statehood and was incorporated into the First Circuit. ${ }^{91}$ All other states entering the Union, however, were established - as Kentucky and Ohio had been - with a federal district court exercising the trial jurisdiction usually reserved for circuit courts. ${ }^{92}$ These courts were quickly overrun with cases. ${ }^{93}$ Congress considered proposals to extend circuit riding or add more circuit courts (and, consequently, to add seats to the Supreme Court) almost every session of Congress after $1815 .{ }^{94}$ In 1825, 1826, and 1830, Congress debated the need for additional circuits at length, but no bill ever won the support of both houses..$^{95}$ When he was in the White House (1825-1829), President John Quincy Adams was largely at

89. Id.; 16 ANNALS OF CoNG. 500 (1807) (recording that the bill was passed without amendment in the House).

90. See Thomas Todd, OYEZ, https://www.oyez.org/justices/thomas_todd [https://perma.cc/QGC2-VWE5] (last visited Sep. 2, 2021). Todd drafted Kentucky's Constitution and served as Chief Justice of the state supreme court when appointed to the Supreme Court. Confirmed in 1807, he served nearly twenty years on the Court, writing only a handful of opinions focused almost exclusively on land claim disputes. $I d$.

91. See Statehood Achieved, Me. State Museum, https://mainestatemuseum.org /exhibit/regional-struggle/statehood-achieved/ [https://perma.cc/B56ESS65] (last visited Sept. 15, 2021); Act of Mar. 30, 1820, ch. 27, § 1, 3 Stat. 554, 554 ("An Act establishing a circuit court within and for the district of Maine.").

92. See Landmark Legislation: Eighth and Ninth Circuits, FED. Jud. CTR., https://www.fjc.gov/history/legislation/landmark-legislation-eighth-andninth-circuits [https://perma.cc/Q8XF-AFYG] (last visited Sep. 25, 2021).

93. Id.

94. Fed. Jud. Hist. Off., Fed. Jud. Ctr., 1 Debates on the Federal Judiciary: A Documentary History 203 (Bruce A. Ragsdale ed., 2013).

95. Id. at $203-04$. 
political odds with Congress ${ }^{96}$ so any legislation that might have given Adams new judicial appointments predictably foundered. ${ }^{97}$

After his election in 1828, Andrew Jackson, a westerner from Tennessee, reminded Congress that a quarter of the nation had no access to a circuit court. ${ }^{98}$ This lack of "a reasonable opportunity afforded for a due administration of the laws" was a common cry among the states admitted after $1807 .{ }^{99}$ Complicated land disputes continued to plague the frontier, with land titles variously granted by other states, foreign governments, and Indigenous tribes. ${ }^{100}$ These questions and other disputes arising out of settlement were most appropriately resolved by a federal court, because they often involved litigation between foreign nationals and U.S. citizens or between indebted citizens of the western states and their eastern creditors. ${ }^{101}$ As the number of potential litigants skyrocketed, with the population tripling between 1807 and 1830, so did the docket of the courts in the Seventh Circuit, the circuit closest to the frontier. ${ }^{102}$ Justice Todd, riding circuit in the distant Seventh Circuit, had to travel some 2,600 miles a year, widely assumed to be the reason for a breakdown in his health. ${ }^{103}$

96. See John Quincy Adams, The White House, https://www.whitehouse.gov/ about-the-white-house/presidents/john-quincy-adams/ [https://perma.cc/ XH8C-X3TK] (last visited Sept. 15, 2021) (recounting some of Adams' conflicts with Congress); Margaret A. Hogan, John Quincy Adams: Domestic Affairs, UnIV. OF VA.: MilleR CTR., https://millercenter.org/ president/jqadams/domestic-affairs [https://perma.cc/BG76-Q7VN] (last visited Nov. 4, 2021) (same).

97. See Orth, supra note 42 , at 684 n.14.

98. See Landmark Legislation: Eighth and Ninth Circuits, supra note 92.

99. See Curtis Nettels, The Mississippi Valley and the Federal Judiciary, 1807-1837, 12 Miss. VAlley Hist. Rev. 202, 202 (1925) (quoting Tennessee Senator Hugh White's speech before the Senate, found in 2 REG. Deb. 524 (1826)). Among the seven states admitted between the 1807 Act and Jackson's election were the trans-Appalachian states of Indiana, Illinois, and Missouri (others were the southern states of Alabama, Mississippi, and Louisiana as well as Maine, carved out of Massachusetts). Id. at 203; see supra text accompanying note 91.

100. See Nettels, supra note 99, at 203-05.

101. See id. at 203-04.

102. See id. at 205. The Seventh Circuit's population increased from 742,000 in 1807 to 2.31 million in 1830. See $i d$.

103. Id. at 205. Litigants also called for judicial reform. In addition to the congestion of the local courts, the absence of access to a circuit court posed particular challenges for criminal justice. Criminal defendants, for example, frequently found their fate solely in the hands of a single district judge. Unlike in the circuit-court system, Supreme Court justices did not preside over these trials. Under the circuit system, a criminal defendant could appeal a case of first impression to the Supreme Court itself. Defendants in states outside of this system had no such option for review; 
Congress debated expanding the number of federal courts and the number of Supreme Court justices on a number of occasions during this era. ${ }^{104}$ Finally, in the 1830s, with Jacksonian Democrats in control of the presidency and both houses of Congress, ${ }^{105}$ re-sizing the Supreme Court became politically possible for the fourth time. Although by 1836 , Jackson had appointed five of the seven members of the Supreme Court ${ }^{106}$-including Roger Taney as Chief Justice ${ }^{107}$ - two additional justices would cement Jacksonian dominance of the Court and could have, perhaps, even overturned Marshall-era precedents. ${ }^{108}$ After Martin Van Buren was elected to succeed Jackson in 1837, Congress expanded the judiciary, creating the Eighth and Ninth Circuits, reorganizing the Seventh Circuit, and expanding the Supreme Court's size to nine members. ${ }^{109}$ President Jackson signed the Act into law on March 3, 1837, the last day of his presidency. ${ }^{110}$ That same day, Jackson nominated John Catron of Tennessee and William Smith of Alabama to the Court. ${ }^{111}$ The newly seated Senate confirmed both nominations,

final judgment lay with the district judge alone. See $i d$. at 206-07. Similarly, for cases involving disputes for less than $\$ 2,000$, parties within the circuit system had the option to appeal the opinion of a district court to the local circuit court. Litigants in the West did not have this opportunity, even though disputes worth $\$ 2,000$ or less constituted most of the disputes in the western states. Finally, even for cases that could, in theory, reach the Supreme Court (such as those involving disputes over $\$ 2,000)$, the expense and difficulty inherent in travelling to Washington posed a significant barrier for many parties. See $i d$.

104. See id. at $224-25$.

105. See F. Andrew Hessick \& Samuel P. Jordan, Setting the Size of the Supreme Court, 41 ARIz. ST. L.J. 645, 666 (2009).

106. Justices 1789 to Present, supra note 76.

107. Id.

108. See Hessick \& Jordan, supra note 105, at 666; see also Reorganization of the Federal Judiciary: Hearing on S. 1392 Before the S. Comm. on the Judiciary, 75th Cong. 342 (1937) (statement of Charles Grove Haines, University of California at Los Angeles) ("President Jackson found it necessary to change the trend of constitutional interpretation. Decisions of the [Supreme] Court on Indian affairs were not enforced. Roger B. Taney was appointed Chief Justice with the intention of changing the course of judicial decisions.").

109. Landmark Legislation: Eighth and Ninth Circuits, supra note 92; Eighth and Ninth Circuits Act of 1837, ch. 34, § 1, 5 Stat. 176, 176-77 ("An Act supplementary to the act entitled 'An act to amend the judicial system of the United States."').

110. See Orth, supra note 42 , at 684 n.14.

111. See Carl B. Swisher, 5 History of the Supreme Court of the United States: The Taney Period, 1836-64, at 62-63 (1974). 
but Smith subsequently declined to serve, giving Van Buren a Supreme Court appointment to begin his presidency. ${ }^{112}$

\section{The Civil War and Reconstruction Eras}

When President Abraham Lincoln took office in 1861, there were nine judicial circuits: five in Southern slave states and four in Northern free states. ${ }^{113}$ Because Supreme Court justices traditionally resided in the circuits they were assigned to oversee, the majority of justices were from slave states. The Southerner-dominated Court had angered Northerners with a series of pro-slavery decisions. The infamous Dred Scott decision of 1857 was especially odious, holding that Black people, enslaved or free, were not citizens of the United States entitled to constitutional rights, ${ }^{114}$ and that enslaved people continued to be enslaved even when transported to free states. ${ }^{115}$ Chief Justice Taney's opinion also declared that the Missouri Compromise, which forbade slavery in certain western territories, was an unconstitutional overreach of Congress. ${ }^{116}$

After Southern states seceded to join the Confederacy, most Southern Congressmen resigned, giving Republicans a solid congressional majority. ${ }^{117}$ Consequently, Congress enacted the Judiciary Act of 1862, which reorganized the circuits so that Northern states comprised

112. See id. at 63, 65-66. President Van Buren appointed John McKinley to the new seat in September of 1837. See also Supreme Court Nominations (1789-Present), supra note 40.

113. Maps of Judicial Circuits, Judgeships, and Meeting Places, FED. Jud. CTr., https://www.fjc.gov/history/exhibits/graphs-and-maps/federal-judicialcircuits [https://perma.cc/6SL3-RFGD] (last visited Sep. 25, 2021).

114. Dred Scott v. Sandford, 60 U.S. (19 How.) 393, 403-04 (1857), superseded by constitutional amendment, U.S. Const. amend. XIV.

115. Id. at 452 .

116. Id. at 399, 452 (interpreting the Constitution's grant of power to Congress to make laws relating to the territory of the United States, found in U.S. Const. art. IV, § 3, cl. 2, to not apply to territories acquired after 1787). Taney's interpretation was the only time the Property Clause was interpreted narrowly, as the Supreme Court has consistently ruled since then that the clause is "without limitation." See Peter A. Appel, The Power of Congress "Without Limitation": The Property Clause and Federal Regulation of Private Property, 86 Minn. L. Rev. 1, 42-43 (2001); Michael C. Blumm \& Olivier Jamin, The Property Clause and Its Discontents, 43 Ecology L.Q. 781, 799 n.116 (2016).

117. See LaJuana Davis, The Legal Implications of the Voting Rights Act Consent Decree on Jefferson County's Government, 40 CumB. L. REv. 815, 820-21 (2009); Gabriel J. Chin, The "Voting Rights Act of 1867": The Constitutionality of Federal Regulation of Suffrage During Reconstruction, 82 N.C. L. REV. 1581, 1589 (2004). 
six circuits, leaving only three made up of Southern states. ${ }^{118}$ This reorganization enabled Lincoln to fill the newly vacant seats in the circuits with Northerners. Soon after the reorganization, the Supreme Court had six Democratic appointees and three Lincoln-appointed Republicans. ${ }^{119}$

In 1863, with the nation seized in the anguish of war, Congress added the Tenth Circuit, bringing the total number of circuits in the free states to seven. ${ }^{120}$ The 1863 Act added a circuit to serve the new states on the Pacific Coast: California and Oregon. ${ }^{121}$ The purpose was primarily logistical; the Western states were so isolated and distant that a separate circuit seemed necessary for the efficient administration of justice. ${ }^{122}$ But the bill was amended to include the addition of a tenth Supreme Court justice. ${ }^{123}$ The Republican Congress thereby succeeded in balancing the Court's membership between Unionists and Taneyaligned holdovers. ${ }^{124}$

With the Confederate states out of the Union, neither the new circuit nor the tenth justice generated controversy. For example, the New York Times story on the additions was buried in a list of end-ofCongress accomplishments that briefly explained that the law's additions "will speedily remove the control of the Supreme Court from the Taney school." 125

118. Judiciary Act of 1862 , ch. $178, \S 1,12$ Stat. 576, 576 (amending the Act of Mar. 3, 1837, ch. 34, 5 Stat. 176).

119. See Justices 1789 to Present, supra note 76. The Democratic appointees on the court when Lincoln took office were James M. Wayne, John Catron, Samuel Nelson, Robert C. Grier, Nathan Clifford, and Chief Justice Roger B. Taney. See id. (listing justices, their dates in office, and the president that appointed them). In 1862, Lincoln appointed Noah H. Swayne, Samuel F. Miller, and David Davis to replace two justices that died and a Southerner who resigned. Id. Swisher, supra note 111, at 815.

120. Tenth Circuit Act of 1863, ch. C, $\S 1,12$ Stat. 794, 794 ("An Act to provide Circuit Courts for the Districts of California and Oregon, and for other Purposes").

121. Id.

122. See Cong. Globe, 39th Cong., 1st Sess. 1259 (1866) (recording the concern that the circuit justice would need to travel so far that the original circuit was impractical).

123. Cong. Globe, 37th Cong., 3rd Sess. 1300-01 (1863).

124. See Swisher, supra note 111 , at $811,830$.

125. According to the New York Times, "The bill providing for a ninth Supreme Court Judge has passed the House, and awaits the President's signature. This Judge will be assigned to the Circuits on the Pacific Coast. $\mathrm{He}$, of course, adds one to the number which will speedily remove the control of the Supreme Court from the Taney school." Important from Washington: The Revenue Bill and Other Important Measures, N.Y. Times, Mar. 4, 1863, at 1. 
As the election of 1864 approached, the North, with the fall of Atlanta that July, had victory in its sights. ${ }^{126}$ For the 1864 election, Republicans rebranded themselves as the National Union Party, and its convention nominated Abraham Lincoln for president and Democrat Andrew Johnson for vice-president. ${ }^{127}$ With the Confederate South unable to cast electoral votes, the bipartisan Lincoln-Johnson ticket won easily. ${ }^{128}$ Soon after the election, Lincoln replaced the recently deceased Chief Justice Taney with Salmon P. Chase, a favorite candidate of the so-called "radical Republicans." 229

Lincoln served less than two months of his second term. When Andrew Johnson took office after Lincoln's assassination in April $1865,{ }^{130}$ the Court was "tied," with five Lincoln appointees and the five remaining members of the Taney court. ${ }^{131}$ Less than two months later, Democratic appointee Justice John Catron died. ${ }^{132}$

Johnson waited almost a year before appointing Catron's replacement. ${ }^{133}$ In the meantime, he demonstrated hostility to the objectives of the radical Republicans' Reconstruction agenda by vetoing the 1865 Civil Rights Bill, ${ }^{134}$ as well as a bill that would have extended

126. With the impending end of the war, Radical Republicans began to lobby Lincoln to severely punish the South and provide substantial assistance to former slaves. See Carl Sandburg, Abraham Lincoln: The Prairie Years AND the War Years 465-77 (1954); Charles Fairman, 4 History of the Supreme Court of the United: Reconstruction AND REunion, 1864-88, pt. 1, at 1 (1971).

127. SANDBURG, supra note 126 , at $515,517-18$.

128. See $i d$. at $182-83,611-12$.

129. See FAIRmAn, supra note 126, at 2; Michael Les Benedict, Salmon P. Chase as Jurist and Politician: Comment on G. Edward White, Restructuring Chase's Jurisprudence, 21 N. KY. L. REV. 133, 140, 142 (1993); see also Xi Wang, Black Suffrage and the Redefinition of American Freedom, 1860-1870, 17 CARdozo L. REv. 2153, 2179 (1995).

130. See SANDBURG, supra note 126 , at 735 .

131. See id. at 616; FAIRMAN, supra note 126, at 1 ; Supreme Court Nominations (1789-Present), supra note 40 (listing justices and their dates in office); The Taney Court, BALLOTPEDIA, https://ballotpedia.org/ The_Taney_Court [https://perma.cc/4HAW-ZSF9] (last visited Sep. 16, 2021) (showing the justices that served with Taney in an easy-to-read list).

132. See FAIRMAN, supra note 126 , at 3.

133. See id. at $161-62$.

134. See id. at 162 . 
the authority of the Freedman's Bureau. ${ }^{135}$ The heavily Republican Congress overrode both vetoes. ${ }^{136}$

In April 1866, President Johnson appointed Henry Stanbery to Catron's seat. ${ }^{137}$ Stanbery was known to share Johnson's hostile views toward Reconstruction. ${ }^{138}$ The Senate never held hearings on the nomination, though. ${ }^{139}$ Two months before Stanbery's appointment, the Chairman of the House Judiciary Committee, James F. Wilson (RIowa), had introduced a bill to reduce the Court's size to nine, saying that he would support even further reductions. ${ }^{140}$ The unmistakable intent was to deprive Johnson of a Supreme Court appointment.

Chief Justice Salmon Chase proposed an even more restrictive restructuring, calling for a reduction in the size of the Court to seven while proposing a near-doubling of the justices' salaries. ${ }^{141}$ Chase drafted the amendment anticipating a second bill that would end circuit-

135. See id. Established by Congress in 1865, the Freedmen's Bureau "was responsible for the supervision and management of all matters relating to the refugees and freedmen and lands abandoned or seized during the Civil War ...." The Freedmen's Bureau, National Archives, https://www.archives. gov/research/african-americans/freedmens-bureau [https://perma.cc/V8W4WYZX].

136. See FAIRMAN, supra note 126 , at 162 .

137. See $i d$. Shortly before being nominated, Stanbery had served "[a]s counsel associated with the Attorney General" and was "the principal draftsman of [President Johnson's] veto message" when Johnson vetoed the Civil Rights Bill of 1866. Id.

138. See id.

139. See id. After the Senate sat on Stanbery's judicial nomination, Johnson nominated him to be Attorney General.

140. Rep. James Wilson, Chairman of the House Committee on the Judiciary, introduced the bill to the House, saying:

We have now an opportunity to reduce [the size of the court] to the old number of nine, and I am satisfied that the business of the court and of the country will be promoted and benefited by a still further reduction. There is now a vacancy on the supreme bench. The purpose of this bill is to avail ourselves of that event so as to reduce the number of judges and again constitute the court of an odd number, and parcel the vacant circuit out among the remaining circuits. That is the sole object of this bill.

I should be in favor myself, from information I have from some of the members of the court, of still further reducing the number if another vacancy now existed; and I think that in the judiciary amendment act it might be well to provide for a further reduction if vacancies should occur.

Cong. Globe, 39th Cong., 1st Sess. 1259 (1866).

141. See FAIRMAn, supra note 126 , at 167. 
riding. ${ }^{142}$ However, Congress accepted only the part of Chase's amendment that reduced the size of the Court, approving it by a mostly party-line vote. ${ }^{143}$ Congress lacked the constitutional authority to remove members of the Supreme Court, so the Act reduced the size of the court by preventing the president from filling vacancies until there were only six associate members. ${ }^{144}$ The change did not seem consequential to the New York Times, which buried its reporting of the diminished Court on page four, with no commentary. ${ }^{145}$

The Act effectively prevented President Johnson from appointing anyone to the Supreme Court and delinked the number of Justices from the number of circuits. ${ }^{146}$ So, in 1867 when Justice James Wayne died, leaving the Court with eight members, Johnson could not appoint a replacement. ${ }^{147}$ If circuit-riding duties had been removed from the Supreme Court, the remaining eight justices might have been adequate for the tasks required of them. But it was soon apparent that the diminishing Supreme Court was accumulating a growing backlog of cases. ${ }^{148}$ Thus, two years later, Congress approved a bill to return the Supreme Court to its pre-war size of nine. ${ }^{149}$ The bill fell victim to a pocket veto by President Johnson. ${ }^{150}$

In 1869, after the hero of the Union's victory, Republican Ulysses S. Grant, took office, Congress entertained several possible fixes to the Supreme Court. ${ }^{151}$ One proposal would have expanded the court to eighteen, enabling half the justices to ride circuit while the other half heard cases in Washington. ${ }^{152}$ In the end, Congress merely restored the

142. S. 103, 39th Cong. (1866) ("To reorganize the judiciary of the United States.").

143. See Fairman, supra note 126, at 168-69; Cong. Globe, 40th Cong., 3rd Sess. 1484 (1869).

144. Judicial Circuits Act of 1866, ch. 210, § 1, 14 Stat. 209, 209 ("An Act to fix the Number of Judges of the Supreme Court of the United States, and to change certain Judicial Circuits.").

145. See Washington News: The Bill Reorganizing the Supreme Court Signed, N.Y. Times, July 23, 1866, at 4.

146. See David P. Currie, The Reconstruction Congress, 75 U. CHI. L. Rev. 383, 432, 476 (2008); see Judicial Circuits Act of $1866 \S \S 1-2,14$ Stat. at 209 (setting the number of justices at seven but keeping nine circuit courts).

147. See William H. Rehnquist, The Supreme Court: "The First Hundred Years Were the Hardest", 42 U. MiA. L. REV. 475, 486-87 (1988).

148. See Fairman, supra note 126, at 247-48; Cong. Globe, 41st Cong., 1st Sess. 207-08 (1869).

149. Cong. Globe, 41st Cong., 1st Sess. 192, 207-08 (1869).

150. Id. at 208.

151. Id. at 207-19.

152. Id. at $209-10$. 
nine-member Court, which gave Grant an opportunity to add a ninth justice to the Court to replace Wayne. ${ }^{153}$

A full decade post-Civil War with a significant majority gave Republicans free reign to further experiment with the Court's size, but they maintained the nine-member Court. Although it was restored to its former size, a lasting outcome of the era was a delinking of the size of the Court from the number of circuits. Even though the number of circuits has grown over the years, and although Congress repeatedly linked the size of the Court to the number of circuits during the first eighty years after the ratification of the Constitution, the Court has had nine members for the last century-and-a-half.

\section{The New Deal Era}

In 1932, Franklin Roosevelt's landslide election promised sweeping economic changes to address widespread poverty that had gripped the nation in the Great Depression. ${ }^{154}$ In his first 100 days in office, Roosevelt led a Democratic Congress to pass a series of bills to regulate and stimulate the economy. ${ }^{155}$ The reaction of the Supreme Court to this avalanche of legislation was highly anticipated..$^{156}$

In early 1935, the Court struck down a provision of the National Industrial Recovery Act (NIRA) as an unconstitutional delegation of power to the president to regulate oil production. ${ }^{157}$ Next, the Court declared the Railroad Retirement Act unconstitutional. ${ }^{158}$ Soon

153. Judiciary Act of 1869 , ch. $22, \S 1,16$ Stat. 44, 44 ("An Act to amend the Judicial System of the United States."); see Supreme Court Nominations (1789-Present), supra note 40 (showing that Grant nominated his first Supreme Court justice in late 1869).

154. See Robert H. Jackson, The Struggle for Judicial Supremacy: A Study of a Crisis in American Power Politics 76 (Octagon Books 1979).

155. See Id. at 77 .

156. See William E. Leuchtenburg, When Franklin Roosevelt Clashed with the Supreme Court-and Lost, Smithsonian Mag. (May 2005), https://www.smithsonianmag.com/history/when-franklin-roosevelt-clashedwith-the-supreme-court-and-lost-78497994/ [https://perma.cc/X8GT-GJJ4]. Robert Jackson, who was well-acquainted with the Roosevelt administration, writes that "speculation turned" about how the Court's swing justices would decide any cases concerning New Deal plans, but also wrote that "[m]ost people, in and out of the Administration, were confident that all was well" with the "New Deal experiments." See JACKSON, supra note 154, at at 83-85; see Solicitor General: Robert H. Jackson, U.S. DEP'T OF JUST., https://www.justice.gov/osg/bio/roberth-jackson [https://perma.cc/JZC2-BHY7] (Oct. 31, 2014) (detailing Jackson's political partnership with Roosevelt).

157. Panama Refin. Co. v. Ryan, 293 U.S. 388, 433 (1935) (popularly known as the "hot oil" case).

158. R.R. Ret. Bd. v. Alton R.R. Co., 295 U.S. 330, 362 (1935). 
thereafter, Roosevelt began privately discussing increasing the size of the Court to protect New Deal legislation. ${ }^{159}$

Then, on a single day, May 27, 1935, the Supreme Court unanimously struck down the NIRA ${ }^{160}$ and the Frazier-Lemke Farm Bankruptcy Act, ${ }^{161}$ and limited the president's power to remove members of independent agencies. ${ }^{162}$ These results caused FDR to speak out publicly against the Court. ${ }^{163}$ In December, Roosevelt privately considered different strategies to work around the Court, including a constitutional amendment to limit the power of the Court to review the constitutionality of legislation. ${ }^{164}$

Opposition to executive power and economic regulation was anchored by a group of four conservative justices disparagingly referred

159. See The Secret Diary of Harold L. Ickes: The First Thousand DAYs, 1933-1936, at 495 (Simon \& Schuster 1953) ("Clearly, it is running in the President's mind that substantially all of the New Deal bills will be declared unconstitutional by the Supreme Court. This will mean that everything that this Administration has done of any moment will be nullified."). Ickes was Roosevelt's Secretary of the Interior and was an important political figure throughout the New Deal era. Harold $L$. Ickes Dead at 77; Colorful Figure in New Deal: Self-Styled 'Curmudgeon' Was Secretary of Interior in Long, Stormy Career, N.Y. Times, Feb. 4, 1952 , at 1 .

160. A.L.A. Schechter Poultry Corp. v. United States, 295 U.S. 495, 541-42 (1935).

161. Louisville Joint Stock Land Bank v. Radford, 295 U.S. 555, 601-02 (1935).

162. Humphrey's Ex'r v. United States, 295 U.S. 602, 629-30 (1935).

163. See Franklin Roosevelt, President of the U.S., Press Conference \#209, at 7-28 (May 31, 1935), in Press Conferences of Franklin D. Roosevelt, 1933-1945, at 309, 315-36 ("I think it is perfectly proper to say further that the implications of this decision could, if carried to their logical conclusion, strip the Federal Government of a great many other powers.") (transcript available at http://www.fdrlibrary.marist.edu/archives/ collections/franklin/?p=collections/findingaid\&id $=508 \quad$ [https://perma.cc/ $236 \mathrm{H}-\mathrm{CCFU}]$ ).

164. See The Secret Diary of Harold L. Ickes: The First Thousand DAYs, supra note 159, at 495 (noting the President proposed "an amendment to the Constitution conferring explicit power on the Supreme Court to declare acts of Congress unconstitutional, a power which is not given anywhere in the Constitution as it stands. The amendment would also give the Supreme Court original jurisdiction on constitutional questions affecting statutes. If the Supreme Court should declare an act of Congress to be unconstitutional, then - a congressional election having intervened - if Congress should repass the law so declared to be unconstitutional, the taint of unconstitutionality would be removed and the law would be a valid one.").

The criticism of the Supreme Court extended beyond the White House. See, e.g., Sidney Ratner, Was the Supreme Court Packed by President Grant?, 50 PoL. SCI. Q. 343, 357-58 (1935). 
to by New Dealers as "the four horsemen of reaction." 165 The four were often joined by two "swing" justices, and sometimes even by members of the court's liberal faction. ${ }^{166}$ The Court held that much of the New Deal legislation exceeded the power of Congress, applying restrictive interpretations of the Commerce Clause. For example, in 1936, the Court voided the Agricultural Adjustment Act, ${ }^{167}$ the Bituminous Coal Conservation Act, ${ }^{168}$ and the Municipal Bankruptcy Act. ${ }^{169}$ Following these decisions, Roosevelt's Attorney General, Robert Jackson, complained that "hell broke loose," since lower courts, following the lead of the Supreme Court, issued over 1,600 injunctions nullifying federal laws. ${ }^{170}$

During his first term, Roosevelt had no opportunity to appoint a justice to the Court. ${ }^{171}$ But after FDR enjoyed another landslide victory in the 1936 elections, he put a court reform plan into motion. ${ }^{172}$ The

165. See Richard A. Maidment, The Judicial Response to the New Deal: The US Supreme Court and Economic Regulation, 19341936 13-15, 129 (1992); Michael Nelson, The President and the Court: Reinterpreting the Court-Packing Episode of 1937, 103 PoL. SCI. Q. 267, 268 (1988). For more information on the "four horsemen," see DREW Pearson \& Robert S. Allen, The Nine Old Men 116, 186, 198, 222 (1936).

166. The Court's four conservative members were Justices Willis Van Devanter, George Sutherland, James McReynolds, and Pierce Butler. The two "swing" members were Justice Owen Roberts and Chief Justice Charles Evans Hughes. The three liberal members were Justices Louis Brandeis, Harlan Fiske Stone, and Benjamin Cardozo. See JACKson, supra note 154, at 82-85; U.S. Supreme Court, Photograph, 1937, U.S. CAPITOL Visitor CTR., https://www.visitthecapitol.gov/exhibitions/ artifact/us-supreme-court-photograph-1937 [https://perma.cc/S397-7X5H] (last visited Nov. 6, 2021).

167. United States v. Butler, 297 U.S. 1, 78 (1936).

168. Carter v. Carter Coal Co., 298 U.S. 238, 309-10 (1936).

169. Ashton v. Cameron Cnty. Water Improvement Dist., 298 U.S. 513, 532 (1936).

170. See JACKSON, supra note 154 , at 115.

171. See id. at 187 .

172. The plan FDR pursued was close to one originally proposed in 1913 by one of the "Horsemen," James McReynolds, when he was President Wilson's Attorney General. Compare 1913 Att'y Gen. Ann. ReP. 5, with President Roosevelt's February 5, 1937 Message to Congress on the Reorganization of the Judicial Branch of the Government, THE Aм. Presidency Project, https://www.presidency.ucsb.edu/documents/ message-congress-the-reorganization-the-judicial-branch-the-government [https://perma.cc/4733-B3NF] (last visited Nov. 6, 2021).

The Supreme Court problem that FDR confronted was due largely to the fact that in 1932, in a Depression-induced austerity measure, Congress cut the Supreme Court justices' retirement salary in half. See Judge 
president's plan would have allowed Justices to retire with a full pension at the age of seventy. ${ }^{173}$ For each justice on the court over that age who had been on the bench for over ten years, the president would appoint an additional justice, up to a total of fifteen. ${ }^{174}$

The plan engendered widespread opposition, even from Democratic leaders in Congress. ${ }^{175}$ After the chair of the House Judiciary Committee refused to pass the bill through his committee, ${ }^{176}$ Roosevelt took to the radio to appeal to the American people in one of his fireside chats. ${ }^{177}$ He argued that his proposal would allow for the speedier administration of justice and introduce the perspective of younger men, with more experience in the modern world, to affect the Court's decision-making. ${ }^{178}$ Warner Gardner, the young research assistant who drafted the plan to oppose "judicial tyranny," speculated that this disingenuous messaging contributed to its failure. ${ }^{179}$

Opposition from the Court itself helped to defeat Roosevelt's plan. On March 21, 1937, Chief Justice Hughes wrote a letter to Congress

Glock, The Lost History of FDR's Court-Packing Scandal, POLITICO (Feb. 24, 2019), https://www.politico.com/magazine/story/2019/02/24/the-losthistory-of-fdrs-court-packing-scandal-225201/ [https://perma.cc/LS2R$\mathrm{S} 9 \mathrm{ZV}$. The upshot was that no justice retired for the next five years, the longest period without a Court retirement since the creation of the ninejustice Court in the 1860s. See id. Congress rescinded the retirement cuts in 1937. See id.; Retirement Act of 1937, ch. 21, 50 Stat. 24; see also Matthew Madden, Note, Anticipated Judicial Vacancies and the Power to Nominate, 93 VA. L. REV. 1156-57 (2007) (noting that the Retirement Act of 1937 allowed justices to remain federal judges in retirement). After that, Willis Van Devanter promptly resigned, giving FDR his longdelayed appointment, which FDR filled with then Senator Hugo Black (D-Ala.); Supreme Court Nominations (1789-Present), supra note 40. By 1941, Roosevelt had made eight appointments, and the era of the New Deal Court was underway. See $i d$.

173. Retirement Act of 1937,50 Stat. 24 (codified as amended at 28 U.S.C. $\S$ $375(1940))$.

174. Judicial Procedures Reform Bill of 1937, S. 1392, 75th Cong. § 1 (1937); Hearings on the Reorganization of the Federal Judiciary Before the $S$. Comm. on the Judiciary, 75th Cong. 1-3 (1937) (reproducing the text of the Judicial Procedures Reform Bill of 1937).

175. See Marian C. McKenna, Franklin Roosevelt and the Great Constitutional War: The Court-Packing Crisis of 1937, at 288 (2002).

176. See id. at 314 .

177. President Roosevelt's March 9, 1937 Fireside Chat, The Am. Presidency Project, https://www.presidency.ucsb.edu/documents/fireside-chat-17 [https://perma.cc/J4UD-MLDY] (last visited Nov. 6, 2021).

178. Id.

179. See Warner W. Gardner, Court Packing: The Drafting Recalled, 1990 J. Sup. CT. Hist. 99, 100, 102. 
denouncing the plan. ${ }^{180}$ His letter was more persuasive because it had the support of both the Court's senior liberal member, Justice Louis Brandeis, and the leader of the conservative block, Justice Willis Van Devanter. ${ }^{181}$ The letter explained that the Court was able to hear all of the cases in its docket and declared that the addition of more justices would not make the Court more efficient. ${ }^{182}$

A week after the Chief Justice's letter, in a decision announced March 29, 1937, the Court upheld a Washington State minimum-wage law, ${ }^{183}$ overturning recent precedent. ${ }^{184}$ Justice Roberts had changed his perspective, and began to be more deferential to the president and Congress. ${ }^{185}$ Then, in May 1937, Justice Willis Van Devanter retired, giving Roosevelt his first appointment and reducing the urgency of efforts to reform the Court. ${ }^{186}$ Roosevelt's bill also ran into political trouble because of the sudden death of its chief congressional sponsor, Senate Majority Leader Joe Robinson (D-Ark.), on July 14..$^{187}$ Robinson's dogged efforts to secure Democratic votes for the proposal seemed to have contributed to his death. ${ }^{188}$ The Senate voted against Roosevelt's court reform bill just over a week later, on July 22, 1937. ${ }^{189}$

Unlike the successful efforts to change the Court's size in the 19th century, Roosevelt's plan to expand the size of the Supreme Court failed. His attempt to do so proved to be a catalyst for a split in the

180. Reorganization of the Federal Judiciary Before the Comm. on the Judiciary, 75th Cong. 488-92 (1937) (statement of J. Burton K. Wheeler reading C.J. Hughes's letter).

181. See Richard D. Friedman, Chief Justice Hughes' Letter on Court-Packing, 1997 J. Sup. CT. Hist. 76, 81 (1997).

182. Id.

183. W. Coast Hotel Co. v. Parrish, 300 U.S. 379, 398-99 (1937).

184. For example, in Adkins v. Children's Hosp. of D.C., 261 U.S. 525, 545, 562 (1923), the Court struck down federal minimum-wage legislation for women as an unconstitutional infringement of liberty of contract, protected by the due-process clause of the Fifth Amendment.

185. See G. Edward White, West Coast Hotel's Place in American Constitutional History, 122 YALE L. J. Online 69, 70-71 (2012), https://www.yalelawjournal.org/pdf/1101_y2wk69v4.pdf [https://perma.cc/ DXG2-9A6E].

186. See McKennA, supra note 175 , at 459.

187. See id. at 504 .

188. See id.; see also Joseph T. Robinson: The "Fightingest" Man in the U.S. Senate, U.S. SEnATE, https://www.senate.gov/artandhistory/history/ common/generic/People_Leaders_Robinson.htm [https://perma.cc/2CNDEKXY] (last visited Sept. 13, 2021).

189. See MCKennA, supra note 175 , at $518,521$. 
congressional Democratic majority, which undermined the Roosevelt Administration's domestic agenda in the years ahead. ${ }^{190}$

\section{Conclusion}

Today, the population of the United States is almost 100 times what it was when the federal court system was established by the Judiciary Act of 1789 and almost ten times what it was when Congress restored the Court to nine justices in 1869. ${ }^{191}$ More than two hundred years of exponential population growth has been accompanied by steady increases in the number of litigants seeking appellate review. ${ }^{192}$ The result, a "crisis of volume," means that those who appeal cases in the federal system are met with long delays and pressure to settle cases. ${ }^{193}$ The enormous volume of cases also impedes litigants' access to the Supreme Court, where the number of petitions for certiorari has trended gradually upwards through the 20th and early 21st century. ${ }^{194}$ The proportion of petitions for certiorari that are granted by the Supreme Court has trended downward from $20 \%$ in 1926 to just $4 \%$ in $2013 .{ }^{195}$

Congress has the power to change both the number of Supreme Court Justices and the size of the lower courts, and to limit the Court's

190. See id. at 554 (explaining that for the remainder of its term, the $75^{\text {th }}$ Congress "did very little legislating"); JAmes T. PATterson, Congressional Conservatism and the New Deal: The Growth of the Conservative Coalition in Congress, 1933-1939, at 216, 217, 219-20 (1967).

FDR's inability to convince Congress to make his Civilian Conservation Corps a permanent program was among the chief casualties of the loss of working control over Congress in the 1938 election. See Douglas Brinkley, Rightful Heritage: Franklin D. Roosevelt and the LAND OF AMERICA 173, 338, 380, 451, 583 (2016) (explaining the CCC, its accomplishments, and its demise), reviewed by Michael C. Blumm, The Nation's First Forester-in-Chief: The Overlooked Role of FDR and the Environment, 33 J. Land Use \& Env't L. 25, 50, 55 (2017).

191. U.S. Census Bureau, Statistical Abstract of the United States: 2012, at 8 tbl.1 (2012).

192. See, e.g., Thomas E. Baker, Rationing Justice on Appeal: The Problems of the U.S. Courts of Appeals 43-50 (1994) (discussing that, due to docket growth, federal appellate cases in 1990 took significantly longer than federal appellate cases in 1950).

193. Report of the Federal Courts Study Committee 109 (Nat'l Inst. of Just. 1990).

194. See Lee Epstein, Jeffrey A. Segal, Harold J. Spaeth, \& Thomas G. Walker, The Supreme Court Compendium: Data, Decisions, \& Developments 72-75 (4th ed. 2007).

195. See $i d$. 
jurisdiction. ${ }^{196}$ To increase litigants' access to the Court, Congress could bolster the Court's ability to take on cases by adding justices to the Court and allowing it to hear cases in panels. Also, Congress could remove cases from the Court's caseload by limiting the Court's jurisdiction so long as the Court retains jurisdiction over the types of cases specifically granted to it by the Constitution. Simultaneously, Congress could expand the existing lower courts' jurisdiction or create specialized courts to hear certain cases. The Biden Commission explored these possibilities, among others, in the report it released in December $2021 .^{197}$

Although the Commission's report was not charged with issuing specific recommendations for the future of the Court, this history makes clear that there are neither constitutional nor historical reasons for thinking that a nine-member Supreme Court is inevitable. ${ }^{198}$ Moreover,

196. The Judicial Branch, The White House, https://www.whitehouse.gov/ about-the-white-house/our-government/the-judicial-branch/ [https:// perma.cc/XP35-W7PP] (lasted visited Aug. 28, 2021).

197. See supra notes 8-10 and accompanying text.

198. For example, of the twelve countries that the World Justice Project's Rule of Law Index 2020 ranks higher than the United States in both "Rule of Law" and "Open Government," seven have high courts with the power of constitutional review that have more members than the United States Supreme Court. These range from twelve members (the Supreme Court of the United Kingdom); sixteen members (the Supreme Court of Sweden and the German Federal Constitutional Court); nineteen members (the Supreme Court of Denmark, the Supreme Court of Estonia, and the Supreme Court of Norway); twenty members (the Supreme Court of Finland); and thirty-six members (Supreme Court of the Netherlands. World Just. Project, Rule of LAW Index 2020 (2020), https:// worldjusticeproject.org/sites/default/files/documents/WJP-ROLI-2020Online_0.pdf [https://perma.cc/C5DR-V76E]; The Supreme Court, JuD. Comm. OF THE PRIVY Council, https://www.supremecourt.uk/about/thesupreme-court.html\#: :text=In\%20October\%202009\%2C\%20The\%20 Supreme,from\%20both\%20Government\%20and\%20Parliament [https:// perma.cc/SV75-2BCY] (last visited Sept. 13, 2021); Sweden, Network of the Presidents of the Sup. Jud. Ct. of the Eur. Union, https://www.network-presidents.eu/page/sweden-0 [https://perma.cc/ 3HWE-VTLT] (last visited Sept. 13, 2021); Structure: Justices, F. Const. CT., https://www.bundesverfassungsgericht.de/EN/Das-Gericht/ Organisation/organisation_node.html [https://perma.cc/YJS9-C4UJ] (last visited Sept. 13, 2021) (Germany's high court); Denmark, Network of the Presidents of the Supreme Jud. Ct. of the Eur. Union, https://www.network-presidents.eu/page/danmark [https://perma.cc/92V78KHV] (last visited Sept. 13, 2021); Estonia, NeTwOrK of THE Presidents of the Supreme Jud. Ct. of the Eur. Union, https://www.network-presidents.eu/page/estonia [https://perma.cc/VB9XPT26] (last visited Sept. 13, 2021); Supreme Administrative Court of Finland, European L. InST., https://www.europeanlawinstitute.eu/ membership/institutional-members/supreme-administrative-court-of-finland/ [https://perma.cc/L46F-TZRM] (last visited Sept. 13, 2021); Norway, 
although the historical record indicates that the size of the Court grew with increased population and the accompanying increase in federal courts of appeal, all adjustments in the size of the Court were politically explainable. From the fractious 1801 and 1802 statutes $^{199}$ to the 1837 statute $^{200}$ to the Civil War changes, ${ }^{201}$ all increases and contractions in the Court's size benefited the political party in power.

The numerous 19th-century changes in the size of the Court seems to have been eclipsed in the modern mind by the so-called "court packing" failure of $1937 .{ }^{202}$ That effort may have been overambitious or unwise, but history shows that it was hardly unconstitutional. And what was considered overambitious or unwise eight decades ago may no longer be in the wake of the Garland and Barrett nominations of the 21st century. The Court's size has remained unchanged since 1869. But this study of the eighty years prior shows Congress repeatedly enacting - consistent with the clear intent of the Framers to leave the size of the Court to the political branches - additions and reductions in the Court's size. No customary practice nor constitutional impediment would stand in the way of altering the Court's size in the future.

\section{ADDENDUM}

On December 7, 2021, the bipartisan commission on the future of the Supreme Court issued its report to President Biden. ${ }^{203}$ The commission's unanimous, nearly 300-page report contained no recommendations, merely discussing the advantages and disadvantages of proposals like expanding the size of the Court or imposing term limits. The panel acknowledged the authority of Congress to enlarge the Court but claimed that there was "profound disagreement" over whether expansion would further politicize the Court. ${ }^{204}$ Although the

Network of the Presidents of the Supreme Jud. Ct. of the Eur. Union, https://www.network-presidents.eu/page/norway\#: :text=The \%20number\%20of\%20justices\%20and,are\%20heard\%20by\%20five\%20just ices [https://perma.cc/8ACA-5ZA5] (last visited Sept. 13, 2021); Netherlands, Network of the Presidents of the Supreme Jud. Ct. of the Eur. UNION, https://www.network-presidents.eu/page/netherlands [https:// perma.cc/39MQ-2S2C] (last visited Sept. 13, 2021).

199. See supra notes $42-76$ and accompanying text.

200. See supra notes 77-112 and accompanying text.

201. See supra notes $113-53$ and accompanying text.

202. See supra notes 120-54 and accompanying text.

203. Presidential Commission on the Supreme Court of the United States, WHITE House (Dec. 7, 2021), https://www.whitehouse.gov/pcscotus/ [https:// perma.cc/XV83-PTW6].

204. See Pamela King, Biden Commission Balks at Supreme Court Expansion, E \& E News: Greenwire (Dec. 8, 2021), https://www.eenews.net/articles/ 
commission expressed some support for term limits, noting "considerable bipartisan support," two prominent members of the commission, retired Judge Nancy Gertner and Professor Emeritus Laurence Tribe, favored expanding the size of the Court over imposing term limits because term limits "cannot be implemented in time to change the court's self-reinforcing trajectory," which includes the Court's "anti-democratic, anti-egalitarian direction of ... decisions about matters such as voting rights, gerrymandering, and the corrupting effects of dark money." ${ }^{205}$ But the commission's lack of recommendations, in the context of a largely deadlocked Congress, seems likely to preserve the Rule of Nine for the immediate future.

biden-commission-balks-at-supreme-court-expansion/ [https://perma.cc/ VU6K-NHP5] (contrasting the Republican stonewalling of confirmation hearings on President Obama's nominee, Judge Merrick Garland, on grounds that seating of a new justice should not occur in the election year of 2016, with the quick confirmation of Judge Amy Coney Barrett just two months after the death of Justice Ruth Bader Ginsburg in the election year of 2020).

205. Nancy Gertner \& Laurence H. Tribe, Opinion: The Supreme Court Isn't Well. The Only Hope for a Cure is More Justices, Wash. Post (Dec. 9, 2021), https://www.washingtonpost.com/opinions/2021/12/09/expandsupreme-court-laurence-tribe-nancy-gertner/ [https://perma.cc/3MWRJ3U9] (" . . . measures the court has enabled will fundamentally change the court and the law for decades. They operate to entrench the power of one political party: constricting the vote, denying fair access to the ballot to people of color and other minorities, and allowing legislative district lines to be drawn that exacerbate demographic differences. As a result, the usual ebb and flow that once tended to occur with succeeding elections is stalling. A Supreme Court that has been effectively packed by one party will remain packed into the indefinite future, with serious consequences to our democracy. This is a uniquely perilous moment that demands a unique response."). 